\title{
A comprehensive appraisal of Sharīah governance practices in Malaysian Islamic banks
}

\author{
Babak Naysary \\ Faculty of Business, INTI International University, Nilai, Malaysia, and \\ Marhanum Che Mohd Salleh and Nurdianawati Irwani Abdullah \\ Department of Finance, International Islamic University Malaysia, \\ Kuala Lumpur, Malaysia
}

\begin{abstract}
Purpose - This study aims to empirically investigate the impact of the Shari' 'ah Governance Framework (SGF) on improving Sharī ah governance practices in Islamic banks in Malaysia and in addressing its related issues.

Design/methodology/approach - Data collection was carried out using a comprehensive questionnaire survey, which was developed primarily based on SGF-2010 and arguments in the literature. The sample for this study includes key functionaries in Sharī'ah governance including senior managers, Sharī' ah committee (SC) and Shar' ${ }^{\prime}$ ah team members of Islamic banks in Malaysia.

Findings - The analysis of scores obtained from the questionnaire survey-including 41 items representing current significant issues in Sharī'ah governance-indicates that SGF-2010 has been successful in achieving its objectives and in addressing related issues. The results of the paired sample $t$-test show significant improvements in Shari' ${ }^{-}$ah governance practices in Malaysian Islamic banks in light of the aforementioned guideline by Bank Negara Malaysia.

Research limitations/implications - Findings of this research suggest that among the five essential pillars of Sharīah governance, namely, accountability and responsibility, independence, competence, confidentiality and transparency, most of the improvements and changes brought about by SGF-2010 are attributable to accountability and responsibility. However, there is still room for improvement in other components of the SGF, particularly with regard to transparency and the independence of the SC and Shari' ah team.

Originality/value - Given the importance of Sharí ah governance and considering recent endeavours to improve Sharī'ah-compliant culture among Islamic banks in Malaysia, this research is among the first attempts to empirically and comprehensively delve into this subject and evaluate its main issues by directly contacting key players in the Islamic banking industry and providing first-hand highlights. This research also compares the findings based on SGF-2010 with the requirements of SGF-2017 and Sharí 'ah Governance Policy Document (SGPD-2019), which were released after this research was completed, where applicable.
\end{abstract}

Keywords Bank Negara Malaysia, Islamic banks, Sharī'ah governance framework, SGF 2010, SGPD-2019, Sharīah committee, Sharī'ah team

Paper type Research paper

(C) Babak Naysary, Marhanum Che Mohd Salleh and Nurdianawati Irwani Abdullah. Published in ISRA International Journal of Islamic Finance. Published by Emerald Publishing Limited. This article is published under the Creative Commons Attribution (CC BY 4.0) licence. Anyone may reproduce, distribute, translate and create derivative works of this article (for both commercial and non-commercial purposes), subject to full attribution to the original publication and authors. The full terms of this licence maybe seen at http://creativecommons.org/licences/by/4.0/legalcode

The research team would like to acknowledge Ministry of Higher Education Malaysia under HUBERT CURIEN PARTNERSHIP - HIBISCUS RESEARCH GRANT SCHEME 2019 (MyPAIRPHC-Hibiscus 2019-1) for the financial support.
381
Sharīah governance practices

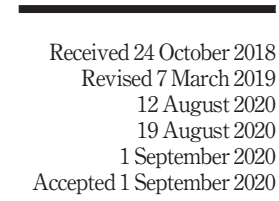

Accepted 1 September 2020 
$\mathrm{IJIF}$

12,3

382

\section{Introduction}

The development of Islamic banking during the past few decades has highlighted the need for the introduction of explicit Sharī' ah guidelines to ensure the application of Sharī'ah principles in this industry. While the Western system of corporate governance is based on self-interest, the ultimate goal in corporate governance in Islamic financial institutions (IFIs) is fulfilling the maqāșid al-Sharī ah (objectives of Islamic law) (Bhatti and Bhatti, 2009). Maqāșid al-Sharî ah is defined as tools to protect and preserve the benefits and interests of society. The inclusion of Shari'ah principles in IFIs and the continuous monitoring of their operations to ensure their compliance with Sharī'ah rulings are what is known as "Sharī'ah governance" (Hasan, 2012). This assurance system not only ensures the sound performance of Islamic banks according to Sharī'ah principles but it also builds trust and confidence among the Muslim ummah (nation) by promoting the principles of transparency and disclosure (Chapra, 2016). However, considering the undeniable role of Shar' ${ }^{-}$ah governance in addressing the issues in Islamic banking, it is still in the early stages of development and faces numerous challenges, which require more attention. In this regard, different standard-setting and regulatory bodies in Muslim countries such as the Accounting and Auditing Organization for Islamic Financial Institutions (AAOIFI), Organization of Islamic Cooperation (OIC), Islamic Financial Services Board (IFSB) and Bank Negara Malaysia (BNM) have tried to regulate Sharī'ah governance practices by issuing guidelines and setting standards.

Aspiring to be the global Islamic finance hub, Malaysia has proved to be a role model in this field and is one step ahead of the rest of the world in regulating its Islamic finance industry, particularly the aspect of Shari' ah governance (Omar, 2013). As the enforcement of the Islamic Banking Act in 1983, the Malaysian regulatory bodies have constantly upgraded the regulatory framework for Islamic finance. In this regard, BNM has played a significant role in issuing Sharīah governance-related guidelines. The Sharī'ah Governance Framework (SGF), which was first issued in 2010 (SGF-2010), is one of the remarkable attempts in designing and establishing an effective Sharī'ah governance mechanism in Islamic banks. The framework was made effective from 1 January 2011 and later revised in 2017 (SGF-2017). SGF-2010 is considered a milestone in the evolution of the Shari'ah governance regulatory framework in Malaysia (Hasan, 2012; Ramli et al., 2014).

However, after almost seven years, as its enforcement, it is observed that there is still limited research on the impact of this framework and its success in addressing the current challenges of Sharīa ah governance in the Malaysian Islamic banking industry. The present research is an attempt to evaluate the impact of SGF-2010 in addressing the current issues in Shari`ah governance. For this purpose, a questionnaire was developed and distributed among key players in the industry who are involved in Sharí'ah governance, including the board of directors (BOD), Sharīah committee (SC) members and senior managers. The respondents were to evaluate the impact of SGF-2010 in addressing and resolving the current challenges in Shari' ah governance. The research later compared the findings based on SGF-2010 with the requirements in the revised SGF-2017 and the Shari' ah governance policy document which was issued in 2019 and now supersedes SGF-2010 (SGPD-2019).

The next section of the paper provides an overview of the literature followed by the research methodology. A questionnaire survey analysis is further provided to outline the research results. Finally, the discussion and conclusion section summarizes the study and its findings.

\section{Related literature}

The issue of Shari' ah governance has been the subject of many studies in recent years, most of them taking a normative view on the issue (Farook and Farooq, 2011; Febianto, 2011; Casper, 2012). In the study by Muhammad and Sulong (2019) on literature related to the 
Shari' ah and corporate governance mechanism, the authors found that different approaches were adopted by different countries, depending on the country's needs, economic situation and regulation. Apparently, most of the literature has examined the roles and responsibilities of BOD and SC including their size, independence, expertise and cross-membership. There are, however, a few exceptions, which scrutinized the fundamental pillars of Shar'1' ah governance in IFIs. Among these researchers, Abdul Rahman et al. (2005) studied Malaysian bank managers' perceptions of the responsibility and independence of Shari'ah advisors. Considering the AAOIFI standards and using questionnaires, their results suggest that, with regard to responsibility, managers believe that Sharī'ah advisors are more responsible towards external stakeholders whose confidence in banks' operations is crucial for the survival of this industry. Regarding the independence of Shari' ah advisors, they found that factors such as the existence of the SC, the level of Sharī'ah background of Sharíah advisors, their reputation, the advisors who are also members of the Shari' ah Advisory Council (SAC) and finally the non-executive role of Sharīah advisors significantly influence the level of independence among Sharīah advisors. Although their research was a great step forward, they took into account only two attributes of the SC and disregarded other influencing factors.

A study by Hamza (2013) argued that the soundness and reliability of Sharīah governance are highly related to the level of independence of the SC and its consistency in pronouncements. According to the author, a menace to the independence of the $\mathrm{SC}$ arises from the fact that SSB members are appointed and remunerated by the IFI, which creates a conflict of interest. In terms of consistency in pronouncements, he mentioned that diversity in opinions and interpretations could be a big challenge for the industry. Studying two different models of SGF in different countries, Hamza (2013) concluded that in decentralized Sharī'ah governance models like Gulf Cooperation Council (GCC) countries, it is more difficult to properly manage the conflict of interest between the SC and IFIs and to reach a consensus in Shari' ah interpretations. On the other hand, in the centralized model, which is implemented in countries such as Malaysia, Pakistan and Sudan, the position and independence of SSB members are stronger and divergence in the interpretations can be more effectively resolved.

Taking into account the conformity of Sharīah governance principles with European governance regulations, Casper (2012) pointed out the issue of independence and competence of SCs. He did not find any obstacle for SC members with regard to independence in the context of Germany, although the lack of competent individuals in both Sharī ah and Islamic banking was found to be a hurdle. His research is unique in the sense that it is among the few studies that considered the issue of Sharíah governance in a non-Muslim country. However, no practical analysis is provided in the context of Sharīah governance in IFIs across Europe.

In his survey in Malaysia, GCC countries and the UK, Hasan (2012) identified six main issues related to Sharī'ah governance. These issues are independence, competence, confidentiality, consistency, disclosure and transparency. Developing a Sharīa ah governance index to measure the quality of Sharī'ah governance in 80 IFIs across Malaysia, the GCC and the UK he found that more than $65 \%$ of IFIs are placed in the "improved practice", "emerging practice" and "underdeveloped practice" of Sharī'ah governance while less than $35 \%$ of them are ranked in the "good practice category". Among the sample countries, Malaysia showed a better performance than other countries where most of the IFIs were ranked in the "good practice" category. On the contrary, GCC countries obtained a weak score and were ranked as "emerging practice". Surprisingly, the findings showed that the UK is in the state of "improved practice" which is better than GCC countries. His study can be considered among the first attempts to quantify the SGF in countries where Islamic banking is practiced, which is a great 
$\mathrm{IJIF}$

12,3

384

step towards a better understanding of this issue. However, it must be noted that out of 22 Islamic banks in the UK, only two banks were selected for the analysis compared to 18 banks in Malaysia and 35 banks in GCC countries. This factor can increase the bias in the research and decrease the ability to generalize the results in the UK.

Emphasizing on Sharī'ah non-compliance risk, Ginena and Hamid (2015) provided firm evidence that there is an urge for developing a comprehensive Sharí' ah governance model to address this unique risk in IFIs. Overall, they affirmed that the competence of the SC and its independence is a challenge for IBs. Furthermore, by comparing different models of SCs, including central authority and decentralized models, they pointed out the roles and responsibilities of SCs and their accountability to key stakeholders. The issue of unity in Shari'ah reference, which indicates consistency in Sharíah rulings, has been pointed out as another key current issue in Sharīa ah governance.

The issue of disclosure in Sharīa ah governance is highlighted by Rahaman (2015), who compared the latest Shari'ah governance regulations on disclosure in Malaysia with international standards (IFSB and AAOIFI). Using the Sharī'ah governance disclosure ratio on the items in the SC report, she found out that Malaysian regulation on Shari'ah governance is more comprehensive than the international ones. However, Rahaman (2015) mentioned that very few Islamic banks comply with this guideline, despite the fact that the deadline for compliance had already passed. Her study calls for more stringent supervision on the implementation of Sharī'ah governance guidelines in Islamic banks.

Highlighting the uniqueness of Sharīah governance structure in Malaysia, Laldin and Furqani (2018) pointed out that SGF-2010, which was updated in 2017, has strengthened Shar' ${ }^{-}$ah compliance in the Islamic finance industry. However, they indicated that to achieve all its objectives, the cooperation of the government, industry players and customers is needed. They also highlighted the significance of the Islamic Financial Services Act (IFSA) 2013 as being legally binding for Shar'̄'ah governance and compliance. Although their study provides an update on the state of the art in Sharī'ah governance, it is still conceptual and more empirical research is required to highlight various aspects in detail. Furthermore, BNM has announced a new guideline on Sharī' ah governance in 2019 that superseded SGF2010; it is called the SGPD-2019. The SGPD basically stresses the role of the BOD, management and the SC (Kamaruddin et al., 2020). A recent study by Kamaruddin et al. (2020) has compared three guidelines related to Shariah governance, including SGF-2010, IFSA-2013 and SGPD-2019. The authors concluded that SGPD-2019 has discussed Sharí ${ }^{-} a h$ governance aspects comprehensively compared to SGF-2010 and IFSA-2013 even though it is suggested that the SGPD-2019 adds few sections on Sharī'ah governance, especially definitions and objectives.

\section{Research methodology}

As an exploratory research, this study opts for quantitative methodology whereby primary data is gathered through a questionnaire survey to evaluate the impact of primarily SGF2010 on addressing the current challenges and improvements in Sharī'ah governance practices in the Malaysian Islamic banking industry. Where needed, the research compares the findings based on SGF-2010 with the requirements in the revised SGF-2017 and the SGPD-2019 and now supersedes SGF-2010 (SGPD-2019).

This study uses a purposive sampling method, which is a deliberate choice of participants based on the qualities that they possess (Zikmund, 2003). The criteria to choose relevant informants in this research are based on the fact that samples must be knowledgeable, experienced and informed about the Sharī'ah governance mechanism and are also involved in the process of SGF-2010 implementation. According to SGF-2010, key 
functionaries in SGF include the BOD, SC members and senior managers and it is they who comprise the samples in this research. Overall, a total of 162 respondents have participated in this study. Descriptive analysis is used in this research to analyse the data gathered through questionnaires. Overall, a paired-sample $t$-test is used to check any significant difference between pre- and post-enforcement of SGF-2010.

\section{Analysis of questionnaire surveys and results}

Questionnaire analysis

After collecting 162 out of 240 distributed questionnaires, which yields the response rate of $67.5 \%$, preliminary data analysis, including data coding, screening and assessment of normality, was performed to check for the robustness of the data. As for the background of the respondents (as shown in Tables 1 and 2), considering that the sample in this research mainly includes people of top positions, questions on the demography of respondents were limited to age, gender and education. The majority of $\mathrm{SC}$ members hold $\mathrm{PhD}$ degrees and their ages range from 35 to 72 years. As for their gender, the majority of SC respondents were male $(85 \%)$ and the rest $(15 \%)$ were female. These figures were different for the Sharīah team, with the majority of respondents holding bachelor degrees. The ages of respondents among the Shari'ah team ranged from 23 to 50 years and their gender ratio was $47 \%$ women and $53 \%$ men.

The study limitations pertain to the survey with regard to time and management constraints which resulted in a relatively low response rate. This issue was partly mitigated

\begin{tabular}{rlccc}
\hline No. & Islamic banks in Malaysia & Shari``ah committee & Sharī`ah team & Management \\
\hline 1 & Affin Islamic Bank Berhad & 4 & 6 & 1 \\
2 & Al Rajhi Banking and Investment & 1 & 6 & 1 \\
3 & Alliance Islamic Bank Berhad & 2 & 6 & 1 \\
4 & AmIslamic Bank Berhad & 4 & 6 & 1 \\
5 & Asian Finance Bank Berhad & 4 & 5 & 0 \\
6 & Bank Islam Malaysia Berhad & 3 & 6 & 1 \\
7 & Bank Muamalat Malaysia Berhad & 5 & 6 & 1 \\
8 & CIMB Islamic Bank Berhad & 4 & 6 & 1 \\
9 & Hong Leong Islamic Bank Berhad & 2 & 5 & 1 \\
10 & HSBC Amanah Malaysia Berhad & 3 & 5 & 1 \\
11 & Kuwait Finance House (Malaysia) Berhad & 4 & 5 & 1 \\
12 & Maybank Islamic Berhad & 3 & 7 & 1 \\
13 & RHB Islamic Bank Berhad & 3 & 7 & 1 \\
14 & Standard Chartered Saadiq Berhad & 3 & 7 & 2 \\
15 & Public Islamic Bank Berhad & 3 & 6 & 0 \\
16 & OCBC Al-Amin Bank Berhad & 52 & 96 & 14 \\
& Subtotal & & & 162 \\
& Total & & &
\end{tabular}

Table 1. List of banks' representatives

\begin{tabular}{|c|c|c|c|c|c|c|c|c|}
\hline & \multicolumn{2}{|c|}{ Position } & \multirow{2}{*}{$\begin{array}{c}\text { Age } \\
\text { Average }\end{array}$} & \multicolumn{2}{|c|}{ Gender (\%) } & \multicolumn{2}{|c|}{ Education (\%) } & \\
\hline & No. & $(\%)$ & & Male & Female & Undergraduate & Postgraduate & \\
\hline $\mathrm{SC}$ & 52 & 32 & 49 & 85 & 15 & 78 & 22 & Table 2. \\
\hline Sharīah team & 96 & 59 & 32 & 53 & 47 & 33 & 67 & Respondents' \\
\hline Management & 14 & 9 & 38 & 62 & 38 & 43 & 57 & background \\
\hline
\end{tabular}


$\mathrm{IJIF}$

12,3

386

by conducting separate interviews with $\mathrm{SC}$ members on the questionnaire items to acquire first-hand information.

This section presents the results obtained from the questionnaire survey. The layout of the questionnaire is categorized based on five main components of Shari'ah governance, each of which encompasses several underlying items. The respondents' views were sought on the pre- and post-enforcement of SGF-2010 based on a five-point Likert scale ranging from strongly agree to strongly disagree. The average of total scores obtained for each item is presented in the tables as percentages.

Table 3 presents the responses to Questions 1 to 9, which relate to issues regarding accountability and responsibility.

When asked about the role of the SC in increasing the awareness on the position of Shari '`ah in Islamic banks (Question 1), the majority of respondents believed that after SGF2010, through the expansion of the role of the SC and an increase in their involvement, the responsibility of informing and increasing people's understanding of the Sharīah now lies with the SC. The ways to discharge this responsibility were found to be, firstly, through regular meetings with managers, the Shari' ah team and banking staff. This is believed to have increased their understanding of Sharīah-related issues. Secondly, by organizing talks and seminars in their capacity as faculty members in universities, SC members can target a wider audience.

\begin{tabular}{|c|c|c|c|c|c|}
\hline & Strongly agree & Agree & Neutral & Disagree & Strongly disagree \\
\hline \multicolumn{6}{|c|}{ Q1: SC is responsible for improving people's understanding of Sharī' ah position on banking transactions } \\
\hline Pre & 1.2 & 3.1 & 40.1 & 54.3 & 1.2 \\
\hline Post & 15.4 & 50.6 & 25.9 & 7.4 & 0.6 \\
\hline \multicolumn{6}{|c|}{ Q2: There is a clear layout of policies, procedures and documentation that SC is responsible to endorse } \\
\hline Pre & 0.6 & 4.3 & 40.7 & 53.1 & 1.2 \\
\hline Post & 11.1 & 54.9 & 27.8 & 4.9 & 1.2 \\
\hline \multicolumn{6}{|c|}{ Q3: Shart ah governance functions include Sharī ah review, Sharī ah audit, Sharī ah risk and Sharī ah research } \\
\hline Pre & 1.2 & 1.9 & 34.0 & 5.6 & 57.4 \\
\hline Post & 34.6 & 38.3 & 22.8 & 3.1 & 1.2 \\
\hline \multicolumn{6}{|c|}{ Q4: SC meetings are held at least once every two months } \\
\hline Pre & 23.5 & 63.6 & 8.6 & 3.7 & 0.6 \\
\hline Post & 30.3 & 55.6 & 12.3 & 1.2 & 0.6 \\
\hline \multicolumn{6}{|c|}{ Q5: SC individual members attend at least 75\% of meetings in a year } \\
\hline Pre & 15.4 & 64.8 & 16.0 & 2.5 & 1.2 \\
\hline Post & 8.0 & 36.4 & 50.6 & 3.7 & 1.2 \\
\hline \multicolumn{6}{|c|}{ Q6: Decisions are made on the basis of $2 / 3$ of present members } \\
\hline Pre & 15.4 & 63.0 & 17.9 & 3.1 & 0.6 \\
\hline Post & 28.4 & 43.2 & 23.5 & 3.7 & 1.2 \\
\hline \multicolumn{6}{|c|}{ Q7: The bank considers profit moderation and contribution to society } \\
\hline Pre & 1.9 & 13.6 & 55.6 & 24.7 & 4.3 \\
\hline Post & 1.2 & 13.0 & 56.8 & 27.2 & 1.9 \\
\hline \multicolumn{6}{|c|}{ Q8: SC has more of a supervisory than an advisory role } \\
\hline Pre & 1.9 & 1.2 & 21.6 & 64.8 & 10.5 \\
\hline Post & 1.2 & 24.7 & 47.5 & 22.2 & 4.3 \\
\hline \multicolumn{6}{|c|}{ Q9: Increase in the number of SC members benefits the quality of their decisions } \\
\hline Pre & 1.9 & 17.3 & 54.3 & 22.2 & 4.3 \\
\hline Post & 9.9 & 53.1 & 32.1 & 3.7 & 1.2 \\
\hline
\end{tabular}

Table 3.

Accountability and responsibility
Pre
Post
17.3
53.1 
On the issue raised in Question 2, the majority of respondents believed that there has been a huge difference after the implementation of SGF-2010 in terms of clarification of the processes and responsibilities, from the structuring of products to the functions and processes related to Shari ${ }^{`}$ ah matters performed in the bank. SGF-2010 was also successful in clearly separating the Sharī'ah team functions (Sharī'ah review, audit, risk and research) and their responsibilities. The auditing by BNM, which is performed annually for Sharīah governance, has been carried out more efficiently after SGF-2010. Also, more detailed information and diligence are in place to make sure all the related documents, including marketing materials and product manuals, are submitted to the SC for approval. The product approval process is also closely monitored. The types of documentation were not clearly outlined before. This was remedied by the enforcement of SGF-2010. The most crucial document that is now constantly reviewed by the Sharīah team is the legal document of products. Apart from documentation, the system and procedures such as methods of profit and revenue calculation, are reviewed by the SC. This is one of the features of SGF-2010 that aims to widen and extend the scope of responsibilities of the SC. The layout of Sharī'ah team responsibilities was found to be very clear and efficient regarding their terms of reference post SGF-2010. However, it is believed that there is still more room for improvement in terms of clarification of specifics.

Regarding Question 3, a significant difference is observed for Sharīah functions, as this segregation of roles was only introduced after SGF-2010. Even in banks with the existence of Sharî' ah organs before, the emphasis and codification on Shari' ${ }^{-}$ah functions in SGF-2010 made the organization of Shari'ah organs more systematized and this generally resulted in more involvement of the Sharīah team in bank performance. This classification and segregation of roles and responsibilities was a significant and positive move for Islamic banks, as by expanding the involvement of the Shari'ah role, many of the activities are delegated to the Shari' 1 ah team, whose performance is crucial for the bank. In some smaller Islamic banks, confusion was observed regarding the difference between the roles of Sharī' ah review and Sharī ah audit after enforcement of SGF-2010. Also, assigning separate individuals to undertake these two functions seems to be a hardship for those small banks; it is not easy for them to comply with it.

On the question of SC meetings referred to in Question 4, the result of the descriptive analysis indicates that there are no differences between pre- and post-SGF-2010 regarding the number of SC meetings conducted in the majority of banks. In this context, as reported by the respondents, the number of meetings depends on the individual banks' practices, which take into consideration the opinion of the SC and top management. Sometimes, numerous occasional meetings were held as per the requirements on a case-by-case basis.

With regard to the attendance rate of SC members, as posed in Question 5, the respondents mentioned that there was not much change with the implementation of SGF2010 and almost all the banks managed to maintain the minimum $75 \%$ requirement of SC members' attendance. For this purpose, it was found that prior arrangements made by the Sharī ah secretariat and the chairman were crucial for meeting the requirements of each SC member while serving the interests of the bank.

Based on the responses to Question 6, it is observed that there is not much difference between pre- and post-SGF-2010 in terms of the decision-making percentage of attendees. The respondents believed that basing decisions on two-thirds of the present members is not an appropriate basis and needs to be revised. Decisions might be subject to different interpretations of members, and in many banks, it was found that there is an influential figure in the SC influencing decisions in meetings. In some cases, even the Chief Executive Officer (CEO) also attended the SC meeting and could exert some influence. In the above cases, the leadership and role of the chairman play a significant role. This requirement has 
been relaxed in SGF-2017 to be a "simple majority". Additionally, although the presence of the BOD and CEO in SC meetings is mentioned in SGF-2017, their presence in decisionmaking sessions is prohibited.

Regarding Question 7, most of the respondents were neutral on the issue of profit moderation and contribution to society. Many of the respondents believed that after SGF-2010, by expanding and enhancing the role of the SC in Islamic banks, more importance is being given to Shari' ah on the ongoing issues in the banks. For example, there is a higher emphasis on ensuring fairness and justice to the customer and other stakeholders. For this purpose, the following are considered the means for achieving profit moderation in Islamic banks:

- zakat (alms) payment;

- corporate social responsibility (CSR) functions (for example, by CIMB Foundation in the case of CIMB Group); and

- income purification (pertaining to Sharī`ah non-compliant income).

There are also other arrangements such as consideration for adjusting financing products; e.g. in the case of home financing, to meet the conditions of people in need (such as paralyzed and disabled) as a means of discharging the bank's responsibility towards society. In these cases, it was found that there is no significant difference pre- and post-SGF-2010 and the issue of profit moderation was an internal policy decided by individual banks.

As for the role of the SC in Islamic banks (Question 8), many of the interviewees believed that SC garners a greater role in IFIs with SGF-2010. The role of the SC is also mentioned in SGPD-2019 where the SC is stated to be responsible "to provide objective and sound advice to the IFI to ensure that its aims and operations, business, affairs and activities are in compliance with Shariah" (p. 22). This mandate has been in practice after SGF-2010 and further enhanced with SGPD-2019. Also, the requirement for continuous endorsement and approval of the products, documentation and processes by the $\mathrm{SC}$ was effective in improving the latter's role. Other respondents separated the roles of the SC into two parts. Firstly, to check whether the product structure the bank is going to offer is Sharīah-compliant. Secondly, check whether there are any issues in the operations of the bank after the product is offered (whether by mistake, negligence or fraud). With respect to operations, SC's responsibility for these actions is minimal and not at par with their optimum accountability.

In response to Question 9, some of the respondents believed that at the beginning the grooming of newly appointed SC members created slight difficulty, particularly due to their lack of prior exposure to practical aspects of Shari`'ah governance. However, over time with more experience, their contribution to the bank has increased. On this particular issue, training has played a significant role. Others mentioned that more rigorous discussions in Shar' 'ah meetings and diversity in SC members' background increased the quality of their decisions. Some of the interviewees were of the opinion that an increase in the number of SC members if accompanied by full adherence to the spirit of shüra (consultation) can be beneficial. However, there can be reduced benefits if there exist influential figures who exercise firm opinions on certain issues - a matter which may nullify the impact of the increase in the number of SC members. The minimum requirement of five SC members is relaxed in SGF-2017 for small and less complex IFIs given proper justifications.

Table 4 shows the respondents' opinions on Questions 10 to 19, which relate to the issue of independence.

According to the respondents' view on Question 10, there is a significant difference between pre- and post-SGF-2010 as the presence of an SC member in the BOD meeting has been fully considered, even though it is still not a mandate and represents merely a 


\begin{tabular}{|c|c|c|c|c|c|c|}
\hline & Strongly agree & Agree & Neutral & Disagree & Strongly disagree & \multirow{4}{*}{$\begin{array}{r}\text { Shari ah } \\
\text { governance } \\
\text { practices }\end{array}$} \\
\hline \multicolumn{6}{|c|}{ Q10: At least one member of the SC is a member of the BOD } & \\
\hline Pre & 0.6 & 1.9 & 21.0 & 66.1 & 10.5 & \\
\hline Post & 8.0 & 40.7 & 29.0 & 9.9 & 12.3 & \\
\hline \multicolumn{7}{|c|}{ Q11: The SC is appointed by the BOD upon the recommendation of its nomination committee } \\
\hline Pre & 65.4 & 7.4 & 24.7 & 1.9 & 0.6 & \\
\hline Post & 55.6 & 24.1 & 18.5 & 1.2 & 0.6 & 38 \\
\hline \multicolumn{7}{|c|}{$\begin{array}{l}\text { Q12: There are an effective communication policy and procedure to facilitate interactions of the SC and } \\
\text { management }\end{array}$} \\
\hline Pre & 1.9 & 15.4 & 56.8 & 21.6 & 4.3 & \\
\hline Post & 1.2 & 7.4 & 60.5 & 29.6 & 1.2 & \\
\hline \multicolumn{7}{|c|}{ Q13: Remuneration of the SC is determined by the bank based on advice from the remuneration committee } \\
\hline Pre & 65.4 & 5.6 & 27.8 & 0.6 & 0.6 & \\
\hline Post & 42.6 & 34.6 & 14.8 & 4.9 & 3.1 & \\
\hline \multicolumn{7}{|c|}{$\begin{array}{l}\text { Q14: There is a clear set of criteria to determine the SC's remuneration which is commensurate with its } \\
\text { duties and accountabilities }\end{array}$} \\
\hline Pre & 1.9 & 16.0 & 54.9 & 22.8 & 4.3 & \\
\hline Post & 1.2 & 11.7 & 62.3 & 24.1 & 0.6 & \\
\hline \multicolumn{7}{|c|}{ Q15: The remuneration system does not affect the independence of the $S C$} \\
\hline Pre & 14.2 & 67.9 & 13.6 & 3.1 & 1.2 & \\
\hline Post & 13.6 & 41.4 & 42.0 & 2.5 & 0.6 & \\
\hline \multicolumn{7}{|c|}{ Q16: The BOD makes sure decisions by the SC are duly observed and implemented in the IFI } \\
\hline Pre & 12.9 & 63.0 & 15.4 & 6.2 & 2.5 & \\
\hline Post & 11.1 & 35.2 & 49.4 & 3.7 & 0.6 & \\
\hline \multicolumn{7}{|c|}{ Q17: There is no obstacle for the SC to access accurate, timely and complete information } \\
\hline Pre & 1.9 & 14.2 & 55.6 & 24.1 & 4.3 & \\
\hline Post & 1.2 & 9.3 & 53.1 & 34.0 & 2.5 & \\
\hline \multicolumn{7}{|c|}{ Q18: There is an effective channel for the SC to inform BNM in case of Shar' ah non-compliant activities } \\
\hline Pre & 1.9 & 13.6 & 58.0 & 22.2 & 4.3 & \\
\hline Post & 1.2 & 33.3 & 40.7 & 22.2 & 2.5 & \\
\hline \multicolumn{7}{|c|}{ Q19: Reappointment, resignation and removal of the SC by the BOD does not affect its independence } \\
\hline Pre & 12.3 & 49.4 & 33.3 & 3.7 & 1.2 & Table 4. \\
\hline Post & 8.6 & 54.9 & 30.9 & 4.3 & 1.2 & Independence \\
\hline
\end{tabular}

suggestion. Through this opportunity, the SC can convey its concerns directly to the BOD. One of the contributions of SGF-2010 is that, in Shari' ah matters, SC members are considered to be of the same rank as the BOD. Therefore, their decisions must be considered and followed thoroughly. In most cases, the SC chairman was also a board member and even sat on the audit committee in some banks. This issue is particularly crucial as the BOD and $\mathrm{SC}$ might have divergent views on certain issues and look at some matters from different perspectives. In this case, the BOD tends to have a more profit- or credit-based view on the issues, which can be further balanced by comments from the SC to ensure Sharīah compliance. The settlement of divergence in BOD and SC opinions is still under question, and a proper solution mechanism has yet to be provided.

In terms of SC appointment in Question 11, there has not been much change before and after SGF-2010; SC members are appointed by the BOD after the recommendation of the nomination committee. It is worth noting that, according to IFSA-2013, any appointment of $\mathrm{SC}$ members must be approved by BNM and all the candidates must comply with the fit and proper criteria, as well as the standards put forward by BNM. 
$\mathrm{IJIF}$

12,3

390

Based on the results, it is observed that there is no significant change pre- and post-SGF2010 for Question 12. Given that a proper channel of communication between the SC and management is crucial, many respondents believed that effective communication is still lacking with regard to the clarity of policies and procedures and that there is more room for improvement. One of the key factors in the lack of proper communication between the SC and management was found to be the lack of understanding of Sharī'ah matters by management and the lack of practical understanding of technical and operational banking matters by the SC.

The SC's remuneration, as in Question 13, must be determined by the remuneration committee and approved by the BOD. It was also found that there was a slight difference in the remuneration of local and foreign SC members (due to alignment with home country remunerations). No significant change was observed after SGF-2010 in this regard.

Question 14 mentions that the remuneration of SC members is highly dependent on the bank's policy and the remuneration committee's decisions and that there is not a predetermined standard criterion. Other than market cap and peer comparison, the size and complexity of offered products seem to influence the level of SC remuneration, which is similar to pre SGF-2010. In the case of foreign Islamic banks, the comparison and balance are maintained based on the group level in the home country and other countries that the group is performing in.

According to the results for Question 15, there is no significant difference pre- and postSGF-2010 on the issue of independence of the SC because of remuneration. SC members have been compared to external auditors and rating agencies which are remunerated by the bank and which have to submit their report to management. However, the measures of independence by BNM play a significant role in maintaining SC's objectivity. Some interviewees mentioned that because of no clear guideline on the individual who commits the Sharī'ah non-compliance cases at the Islamic bank's level, the SC, in general, would be responsible for the entire case. The opinion of the SC in any case of Sharī'ah non-compliance (even if they receive high remuneration from the bank) cannot be compromised. It was also mentioned that after SGF-2010 the independence of the SC became more important because:

- There are a direct channel and possibility for SC members, particularly the chairman, to contact and communicate with BNM on any matter of concern.

- Any dismissal or termination of SC membership should rigorously be accompanied by clear justifications and obtain the approval of BNM first.

- On a case-by-case basis, it was found that were there inquiries and monitoring by $\mathrm{BNM}$ of any pressure or interference by the BOD or management.

- The reason for any resignation by $\mathrm{SC}$ members is thoroughly monitored and evaluated by BNM.

Regarding Question 16, in some banks, the SC regularly updates the BOD on any outstanding rectification measures that need to be carried out. The decision of the SC, even if it leads to a decrease in profit, must be followed and implemented by the bank. It can even halt the offering of certain products which are doubtful with regard to their Shari'ah compliance. For this purpose, the minutes of SC meetings are the basis for any subsequent actions. The person in charge of conveying the extracted meaning of SC meetings is the Shari' ${ }^{\prime}$ ah secretariat, which also acts as one of the main channels of communication between the SC, business units and management. However, the monitoring measure to make sure that the decisions and extract the meaning of SC meetings are properly and completely communicated to management needs to be improved. 
Regarding Question 17, although it was mentioned that there are no restrictions on the $\mathrm{SC}$ accessing accurate and timely information, in some cases the Shari' ah team found practical difficulties in getting timely information. Completeness of information was another issue, and the main reason for that was found to be the different understanding of staff in business units who are supposed to provide the required information. The lack of understanding can be due to misconceptions about their roles and responsibilities, as well as their different views on the product and nature of the information that they are required to provide. Therefore, on this issue, there is room for improvement and for regulatory considerations.

Based on the respondents' views on Question 18, there has been a difference between pre- and post-SGF-2010 for item 18. The cases of Sharī' ah non-compliance can be found and inspected by various individuals such as Sharī'ah reviewers and auditors; however, they need to first inform the SC to decide whether it is an actual Sharī ah non-compliance event or not. From this point on, the procedures can vary between banks. For example, the ultimate reporting unit can be the Shar'`'ah compliance or Sharī'ah risk unit. In most cases, the SC does not directly report to BNM as they will try to discuss the case internally before making any decision. The SC's engagement with BNM is on a case-bycase basis, mostly if there is any call from BNM for meeting and during the annual Sharīah audit by BNM. Generally, any communication with BNM should be done by the Regulatory Compliance Unit (RCU) and cannot be done directly by any staff.

No significant change was noted in terms of reappointment, resignation and removal of the SC in pre- and post-SGF-2010 (Question 19). However, it must be noted that the removal of any SC member can be done by the BOD only by providing complete and clear reasons to $\mathrm{BNM}$. Therefore, the independence of the SC is duly protected. It was mentioned by most of the respondents that generally there are rigorous requirements in case of removal or resignation of SC members by BNM. This is so, as according to IFSA-2013, Islamic banks should notify BNM of the fact and the reasons not later than 14 days of such a circumstance.

Table 5 shows the response to Questions 20 to 28 pertaining to the issue of competence.

Relating to the question of whether the chairman of the SC is of Sharī'ah background (Question 20), although this requirement is mentioned in SGF-2010, it was also the case before its enforcement in most of the banks. Normally, the chairman of the SC must have obtained his/her first degree in Sharī'ah. A more elaborate outline of the chairman's responsibilities is provided in SGF-2017.

Fit and proper criteria, as mentioned in Question 21, have not been changed significantly by SGF-2010 due to the fact that most of these criteria are still determined based on internal strategies and requirements of banks. Apart from SGF-2010 requirements, Islamic banks have their own set of fit and proper criteria for the appointment of SC members. In some cases, these criteria can be affected by views and expectations of the management of the bank. As reflected in the response to Question 22, the main focus among banks is still on a Sharīah degree. There are even some cases where all SC members have a Sharīah background. This led to situations where SC members lack the necessary knowledge in banking and finance. In this regard, not much change was found before and after the enforcement of SGF-2010. However, it is worth mentioning that Islamic banks are becoming aware of the need for having a more diversified background among SC members.

There is no significant difference pre- and post-SGF-2010 on the response to Question 23. Depending on the banks' internal policy and strategy, some banks might favour extensive knowledge on fiqh al-mu'ämatät (Islamic commercial law) while others consider the academic background and $\mathrm{PhD}$ qualifications in Islamic banking and finance. After enforcement of SGF-2010 because of more involvement of SC members in daily operations of 


\section{IJIF \\ 12,3}

\begin{tabular}{|c|c|c|c|c|c|}
\hline & Strongly agree & Agree & Neutral & Disagree & Strongly disagree \\
\hline \multicolumn{6}{|c|}{ Q20: Chairman of the SC is a member with a Shari ah background } \\
\hline Pre & 15.4 & 58.7 & 16.7 & 4.9 & 4.3 \\
\hline Post & 7.4 & 54.3 & 32.7 & 4.3 & 1.2 \\
\hline \multicolumn{6}{|c|}{ Q21: There is a clear set of fit and proper criteria for the appointment of SC members } \\
\hline Pre & 14.8 & 65.4 & 17.9 & 1.2 & 0.6 \\
\hline Post & 9.3 & 53.1 & 32.1 & 4.3 & 1.2 \\
\hline \multicolumn{6}{|c|}{ Q22: SC members have sufficient knowledge and experience in banking and finance } \\
\hline Pre & 1.2 & 3.7 & 21.6 & 64.2 & 9.3 \\
\hline Post & 0.6 & 1.9 & 25.9 & 42.0 & 29.6 \\
\hline \multicolumn{6}{|c|}{ Q23: SC members have sufficient knowledge and experience in Islamic banking and finance } \\
\hline Pre & 1.9 & 3.1 & 22.2 & 62.3 & 10.5 \\
\hline Post & 1.2 & 3.1 & 25.9 & 40.7 & 29.0 \\
\hline \multicolumn{6}{|c|}{ Q24: SC members have sufficient knowledge and experience in fiqh al-mu'āmalāt } \\
\hline Pre & 30.3 & 51.2 & 13.6 & 4.3 & 0.6 \\
\hline Post & 25.3 & 45.7 & 25.9 & 2.5 & 0.6 \\
\hline
\end{tabular}

Q25: There is an effective training programme in place to constantly equip SC members with relevant knowledge in Sharī ah and finance

\begin{tabular}{|c|c|c|c|c|}
\hline Pre & 1.9 & 4.9 & 17.9 & 64.8 \\
\hline Post & 8.0 & 51.9 & 32.7 & 4.9 \\
\hline
\end{tabular}

Q26: There is no restriction for SC members to seek advice and assistance from other professionals such as external Sharī ah advisors, lawyers, accountants and economists

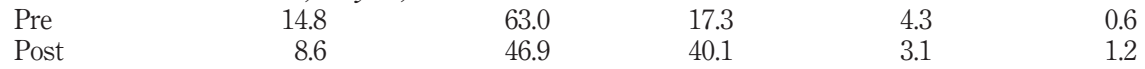

Q27: There is a formal process of assessing the performance of the SC in terms of competency, knowledge, contribution and effectiveness

$\begin{array}{lrrrrr}\text { Pre } & 8.6 & 50.0 & 37.0 & 3.7 & 0.6 \\ \text { Post } & 13.0 & 44.4 & 37.0 & 4.3 & 1.2\end{array}$

Q28: There is an effective succession planning programme for SC members by identifying, hiring and

Table 5. nurturing new members

Pre 1.9

$\begin{array}{ll}\text { Post } & 1.2\end{array}$

1.9

$5.2-54.9$

54.3

24.7

35.2

the bank, banking and finance qualification and experience are considered among the main criteria for choosing SC members. However, still many banks mainly consider the Shari ‘ah background of members to be more important. It is worth noting that in SGF-2017, this issue is addressed by requiring at least one Islamic banking and finance expert with a minimum of 10 years' experience.

The requirement for SC members to have a Sharīah background as in Question 24 did not change pre- and post-enforcement of SGF-2010 and the focus on having a Sharíah degree and knowledge is still the main criteria.

Based on the results for Question 25, it is found that there is a significant difference preand post-SGF-2010 on the training programmes for SC members in both banking practices and Sharīah methodology. The requirement for an effective and continuous training programme has led Islamic banks to formulate internal and external measures for training SC members. In almost all banks, there is an annual budget allocated for training programmes. It can be spent in the form of attending workshops and seminars and in the form of research conducted by SC members. The latter is observed to be becoming more significant, as many of the $\mathrm{SC}$ members are academics. An example of a comprehensive training programme 
conducted by the Association of Shariah Advisors in Islamic Finance (ASAS) endorsed by BNM is the Certified Shariah Advisor (CSA) and the Certified Shariah Practitioner (CSP), which are offered not only to the SC but also the Shari'ah team. Failing to participate in training programmes affects the renewal of SC members' licenses. Training of SC members has also become one of the key elements based on which SC members' performance is assessed. Although there was no fixed and organized policy and procedure for training SC members, SGPD-2019 (Standard 9.5, page 8) reminded the board "to allocate sufficient resources for continuous development of skills and expertise of the Shariah committee" (BNM, 2019). This is to ensure that the SC members are competent with the required knowledge and skills to fulfil their responsibilities.

Regarding the issue highlighted in Question 26, some banks have "subject matter experts" and permanent invitees in SC meetings to seek their views on related issues, provide clarifications to SC members and obtain alternative opinions on issues at hand. It is found that there is no significant change after the implementation of SGF-2010 on the question of getting external advice and assistance, although, in the case of big banks, it has become less frequent.

On the question of assessing SC performance as posed in Question 27, it is found that there is no significant difference pre- and post-SGF-2010. On the issue of whether there is a formal process of assessment of SC performance, it is found that no structured and unified framework was in place. Each individual bank has its own assessment mechanism. For example, in most cases, each SC member is responsible for assessing other members' performance and effectiveness. The chairman is mainly responsible for assessing the performance of SC members, and subsequently, they appoint a member to evaluate the performance of the chairman. For the purpose of performance evaluation, there is a form prepared by the bank for gauging the contribution and deliverables of SC members with regard to assigned tasks, their contribution in meetings and their response rate to emails and calls from the bank for clarification of emergency issues. The chairman, in some cases, is assessed by the BOD on an annual basis. The rating system also became more organized and emphasized after SGF-2010.

On the question of succession planning referred to in Question 28, no significant change was observed. Despite the fact that the need for succession planning programmes was stipulated in SGF-2010, no particular planning policy was mentioned by the respondents other than rotations in SC chairmanship every two years to equip members with the necessary experience.

Table 6 provides the response to Questions 29 to 34, which relate to the issues of confidentiality and consistency.

The key measure to ensure awareness of SC members on the issue of confidentiality and secrecy (Question 29) is that they are informed and educated on the matter before the appointment. This has not changed significantly after SGF-2010. The issue of confidentiality is found to be well understood by SC members. The main material that is explained to SC members to enhance their understanding of confidentiality is the "Personal Data Protection Act". The concern among practitioners is that, as some of the SC members are academics, the real case examples of the bank might be expressed as educational tools, which raises the issue of confidentiality.

The issue of communication between the $\mathrm{SC}$ and BNM as posed in Question 30 was not found to be a matter of concern by respondents, as there are arrangements put in place by BNM enabling their direct communication. Disclosure of information by the bank to any party must be in line with the "Personal Data Protection Act". However, in the case of crime and terrorism, disclosure is not restricted. There were no significant changes pre- and postSGF-2010 on this matter. 


\section{IJIF \\ 12,3}

\section{4}

Table 6.

Confidentiality and consistency

\begin{tabular}{l}
\hline Strongly agree \\
\hline Q29: There is a procedure to inform and make the SC fully aw \\
information and documentation that are not public in nature \\
Pre 9.9
\end{tabular}

Pre

10.5

53.7

28.4

1.2

1.2

Q30: If sensitive information is reported to BNM by the SC in good faith, it is not regarded as a violation of confidentiality

$\begin{array}{llllll}\text { Pre } & 14.2 & 64.8 & 17.3 & 2.5 & 1.2 \\ \text { Post } & 30.2 & 43.8 & 21.6 & 3.1 & 1.2\end{array}$

Q31: Restrictions for SC members to sit on the SC of only one IFI in the same industry have improved the quality of decisions

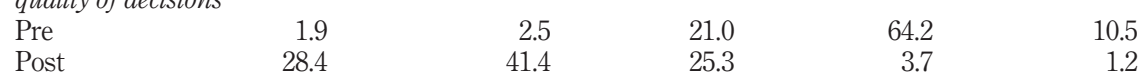

Q32: The concept of shüra is carried out in a proper and consensual manner between key players in Sharī'ah governance

$\begin{array}{lrrrrr}\text { Pre } & 1.9 & 15.4 & 60.5 & 17.9 & 4.3 \\ \text { Post } & 7.4 & 40.7 & 46.9 & 3.7 & 1.2\end{array}$

Q33: The SC is influential in promoting strict adherence to ethics and the Islamic moral code

$\begin{array}{lrrrrr}\text { Pre } & 1.9 & 14.2 & 56.2 & 23.5 & 4.3 \\ \text { Post } & 27.2 & 43.8 & 23.5 & 4.3 & 1.2\end{array}$

Q34: There exists a fair level of gender diversity among SC members

$\begin{array}{llllll}\text { Pre } & 13.0 & 51.3 & 32.1 & 2.5 & 1.2 \\ \text { Post } & 24.7 & 43.8 & 25.9 & 4.3 & 1.2\end{array}$

On Question 31, it is found that there is a significant difference between pre- and post-SGF2010. Restrictions for SC members to sit on the SC of one IFI in the same industry have both pros and cons. For example, while sitting on multiple boards could be beneficial in terms of $\mathrm{SC}$ members' access to knowledge and expertise, given that they need to be involved with many IFIs at the same time, the question of their ability and availability for properly serving these IFIs is raised. However, one of the shortcomings of this regulation can be the creation of a temporary shortage of Sharīah scholars. In the early stages of SGF-2010, it is noted that this restriction did create a surfeit of Sharía ah scholars in the Islamic banking industry. However, later on, more talents, mainly from among academics, were recruited on Sharī ah committees, which proved to be beneficial for the industry. There is also the issue of confidentiality, which is especially of concern to the banking industry, which is highly competitive.

There is a difference in responses for Question 32 between pre- and post-SGF-2010. The issue of $s h \bar{u} r \bar{a}$ has been recently brought up as one of the essential factors for the proper functioning of the SC. The new regulation on restricting SC members from sitting on other IFIs' committees in the same industry has, to some extent reduced the issue of fatwa shopping. It has also provided a new ground for different opinions to be expressed on various subject matters which is more in line with the spirit of shüra.

The results for Question 33 indicate a difference in respondents' opinions between preand post-SGF-2010. This issue was highlighted by the empowerment of banks' SCs after SGF-2010. For example, in some cases which apparently are not against Sharīa ah principles (e.g. investments in the condom industry), the SC can consider Islamic ethics, moral codes and the subsequent impact on Muslim customers' perceptions of the bank's operations, and thus restrict the bank's involvement in these areas. Further examples can include activities such as night clubs and certain TV commercials if they are against the Islamic moral code of 
conduct. Events and promotions are also referred to as the SC to validate their ethical elements. Respondents further mentioned that this can be in the form of promoting proper attire. However, in SGF-2017, as mentioned in the "Shar'` ah compliance culture" section, the focus now seems to be more on the integration of Sharī'ah governance considerations in business and risk strategies, as well as internal policies which fall under the prerogative of the BOD as the party of authority on these matters.

The issue of diversity raised in Question 34 is one of the current trends in the Islamic banking industry that have been brought up in current research. Although in most cases, men outnumber women in SCs, the priority is on qualification and gender is not a criterion for appointing SC members. In Malaysia, generally, there is no discrimination against female employees and Islamic banks are not an exemption. Unlike local banks, in some foreign banks considerations regarding the gender of SC members have been mentioned by respondents.

Table 7 shows the responses to Questions 35 to 41 relating to the issues of transparency and disclosure.

No significant difference in respondents' opinions is found in Question 35. Although not mentioned in SGF-2010, the guidelines on financial reporting for Islamic banks by BNM stipulate that the annual reports - which also include the SC reports in Islamic banks - must be published in local newspapers in two languages (national language and English). This issue is particularly of significance considering the diverse nature of customers and stakeholders in Islamic banks in Malaysia to make sure that they have access to annual reports information in a proper and useful manner.

\begin{tabular}{|c|c|c|c|c|c|c|}
\hline & Strongly agree & Agree & Neutral & Disagree & Strongly disagree & \\
\hline \multicolumn{7}{|c|}{$\begin{array}{l}\text { Q35: The IFI publishes its annual financial report including the SC's report in at least two local daily } \\
\text { newspapers with one in the national language and the other in English }\end{array}$} \\
\hline Pre & 14.8 & 70.4 & $10.5^{\circ}$ & 3.7 & 0.6 & \\
\hline Post & 10.5 & 54.9 & 29.0 & 4.3 & 1.2 & \\
\hline \multicolumn{7}{|c|}{$\begin{array}{l}\text { Q36: There is a clear set of requirements on disclosing information on payment, responsibility, calculation } \\
\text { method and beneficiaries of zakat in the annual report }\end{array}$} \\
\hline Pre & 14.8 & 61.7 & 21.0 & 1.9 & 0.6 & \\
\hline Post & 22.2 & 46.3 & 29.0 & 1.9 & 0.6 & \\
\hline \multicolumn{7}{|c|}{ Q37: The SC provides written Shari ah opinions when the IFI submits applications for new product approval } \\
\hline Pre & 15.4 & 63.5 & 16.7 & 2.5 & 1.9 & \\
\hline Post & 9.3 & 47.5 & 37.7 & 4.3 & 1.2 & \\
\hline \multicolumn{7}{|c|}{ Q38: The number of SC meetings in a year is disclosed in the IFI's annual report } \\
\hline Pre & 1.9 & 14.2 & 58.0 & 21.6 & 4.3 & \\
\hline Post & 1.2 & 14.8 & 51.9 & 31.5 & 0.6 & \\
\hline \multicolumn{7}{|c|}{ Q39: The attendance rate of every SC member in the meetings is disclosed in the IFI's annual report } \\
\hline Pre & 2.5 & 6.2 & 61.1 & 25.9 & 4.3 & \\
\hline Post & 1.2 & 8.0 & 55.0 & 35.2 & 0.6 & \\
\hline \multicolumn{7}{|c|}{ Q40: The remuneration of SC members is disclosed in the IFI's annual report } \\
\hline Pre & 1.9 & 14.8 & 56.2 & 22.8 & 4.3 & \\
\hline Post & 1.2 & 8.0 & 58.7 & 31.5 & 0.6 & \\
\hline \multicolumn{6}{|c|}{$\begin{array}{l}\text { Q41: There exists a clear and detailed set of requirements for Sharī ah reporting disclosure in the annual } \\
\text { report }\end{array}$} & Table 7. \\
\hline Pre & 1.9 & 1.9 & 18.5 & 67.3 & 10.5 & Transparency and \\
\hline Post & 10.5 & 56.8 & 27.2 & 4.3 & 1.2 & disclosure \\
\hline
\end{tabular}


Respondents' views on Question 36 did not differ significantly. Sources and destinations of zakat are disclosed in general, but not elaborately. This disclosure is also more emphasized after SGF-2010. Some of the banks have zakat committees; however, for the distribution of zakat, they need to consult the SC. Zakat is also paid to local authorities; however, in most cases, they return the amount to the bank on the basis of wakälah (agency). Therefore, in this case, the bank acts as an agent for the distribution of zakat. The disclosure of zakat collection and distribution is found to be limited and general with no comprehensive report made available on this matter. The methods of zakat calculation are disclosed in annual reports.

No significant difference is found for Question 37 between pre- and post-SGF-2010. Sharī ah pronouncements (official Sharī`ah opinions) are accessible to the public. However, it is not the case for retail products. Product disclosure sheets that highlight critical features of products and describe underlying Sharī'ah principles are another means for ensuring transparency on products by Islamic banks.

As presented in Question 38, most of the respondents believe that there is no difference pre- and post-implementation of SGF-2010 on the disclosure of the number of meetings in the IFI's annual report. Although there are different opinions among respondents regarding the disclosure of SC meetings in the annual report, a review of the Islamic banks' annual reports reveals that after enforcement of SGF-2010 banks tend to disclose the number of SC meetings to comply with this guideline.

As stated in Question 39, in terms of disclosure of the attendance rate of SC members, the majority of respondents were neutral. Hence, apart from the respondents' views, a review of annual reports was conducted, which revealed that there are a number of Islamic banks that do not disclose such related information. In some banks that disclose the number of meetings, this information is merely mentioned in the SC report and there is no further disclosure on the attendance rate.

The results of Question 40 show that SGF-2010 did not cause any difference in terms of $\mathrm{SC}$ remuneration disclosure in Islamic banks' annual reports. Islamic banks' policies in this regard have not changed after SGF-2010 as the guideline does not require the disclosure of $\mathrm{SC}$ members' remuneration. However, as mentioned in the literature, it is one of the tools for transparency, as it has implications for SC members' independence (Hamza, 2013; Fatihah, 2015).

According to the results of Question 41, respondents opined that before SGF-2010 there was no clear and detailed set of requirements for SC report disclosure in the annual report. Hence, the SC report has improved comprehensively after SGF-2010. There was a general belief among the respondents that the comprehensiveness of the $\mathrm{SC}$ report must be accompanied by considerations on the balance between confidentiality and public interest. As the main users of annual reports are shareholders and as not many Islamic banks are listed on the Kuala Lumpur Stock Exchange (KLSE), the requirements on the Sharīah report are still limited. Given this fact, there is still room for elaborating on the $\mathrm{SC}$ report. Detailed information on the contribution of Islamic banks to the society can also better inform stakeholders on the nature of operations undertaken by banks (such as waqf (Islamic endowment) and șadaqah (voluntary charity)), as the SC report is considered a tool to communicate to the public on Sharī ah governance activities. The SC report can be further improved by including more information on the tasks that Sharī'ah review, audit, risk and research undertaken to ensure Sharīah compliance. Other information that can be included in the SC report is the number of events and profit generated from Sharī'ah non-compliance activities and measures taken by the bank to address and resolve these issues. 
Final results: evaluating the perceived changes in Sharī'ah governance practices pre- and post-enforcement of Sharī ah governance framework-2010 This section analyses the perceived changes in Sharīah governance practices as measured through questionnaire scores pre- and post-SGF-2010. For this purpose, the data were divided into two sets pertaining to pre- and post-SGF-2010, and the mean for each set was calculated in SPSS for every question. To check for any significant difference between Sharī'ah governance practices pre- and post-SGF-2010, a paired sample $t$-test was used on the means of these two groups. The paired sample $t$-test was found to be appropriate due to the fact that among two types of $t$-test, the independent $t$-test is used when there are two experimental conditions with two different participants while the paired sample $t$-test applies when the same participants take part in pre-test and post-test (Field, 2009). Table 8 shows the descriptive statistics for paired sample $t$-test for scores pre- and post-SGF-2010.

According to $t$-test results presented in Table 8, a significant difference is found for Shari ${ }^{-}$ah governance scores as measured by the questionnaires before (Mean $=2.8, \mathrm{SE}=0.12$ ) and after $\mathrm{SGF}-2010$ (Mean $=2.5, \mathrm{SE}=0.09) ; t(40)=2.43, p=0.020$. The results of the $t$-test reflect the fact that, according to the respondents' perception, Shari 'ah governance practices in Islamic banks in Malaysia have improved significantly after SGF-2010. Overall, this significant change is mainly attributable to the accountability and responsibility component. (Table 9)

\section{Discussion and conclusion}

This research is an attempt to investigate the effect of SGF-2010 in Malaysian Islamic banks relying on the survey method as the data collection tool to achieve the research objectives. The results of the paired-sample $t$-test on the items in the questionnaire, which was intended to measure the degree of the change prior to and after the implementation of SGF-2010, indicated a significant difference, implying that generally Sharī'ah governance practices have significantly improved after the enforcement of SGF-2010. The major changes in Shari'ah governance practices are mostly attributable to the improvements in the accountability and responsibility component. This is consistent with the study of Shafii et al. (2013), who mentioned that expansion and elaboration on the roles and responsibilities of the $\mathrm{SC}$ and inclusion of Sharī' ah functions are believed to have added value to the operations of Islamic banks in terms of assuring compliance with Sharī'ah principles.

\begin{tabular}{lcccc}
\hline & Mean & $n$ & SD & Std. error mean \\
\hline SGpractices & & & & \\
Pre & 2.7948 & 41 & 0.75172 & 0.11740 \\
Post & 2.5437 & 41 & 0.56894 & 0.08885 \\
\hline
\end{tabular}

Table 8.

Descriptive statistics for paired sample $t$-test for Sharī'ah governance scores pre- and postSGF-2010

\begin{tabular}{|c|c|c|c|c|c|c|c|c|c|}
\hline & & & & $\begin{array}{l}95 \% \text { con } \\
\text { of th }\end{array}$ & $\begin{array}{l}\text { interval } \\
\text { ence }\end{array}$ & & & & $\begin{array}{r}\text { Table } 9 . \\
\text { Paired samples test }\end{array}$ \\
\hline & Mean & SD & $\begin{array}{l}\text { Std. error } \\
\text { mean }\end{array}$ & Lower & Upper & $t$ & $\mathrm{df}$ & $\begin{array}{c}\text { Sig. } \\
\text { (two-tailed) } \\
\end{array}$ & $\begin{array}{l}\text { governance } \\
\text { scores pre- and post- }\end{array}$ \\
\hline Pre-post & 0.25113 & 0.66161 & 0.10333 & 0.04230 & 0.45996 & 2.43 & 40 & 0.020 & SGF-2010 \\
\hline
\end{tabular}


$\mathrm{IJIF}$

12,3

398

In addition, the elements which improved significantly after the implementation of SGF2010 include the following:

- The position of the SC as a reference point and its role in enhancing the understanding of Sharī'ah; clearer demarcation of responsibilities.

- Expansion of the Sharīa ${ }^{`}$ h team function.

- Increase in the minimum number of SC members to enhance the quality of their decisions.

- The recommendation of SGF-2010 for the presence of an SC representative in the BOD was found to be a positive move by BNM.

- There are some initiatives regarding the training programmes both at the BNM level and the internal level of the bank after SGF-2010.

- Restrictions on SC members to sit on more than one committee within the same industry are believed to have improved the concept of $s h \bar{u} r \bar{a}$, mitigated competitive risks and helped nurture new scholars in the industry.

Although Sharīa reporting has improved after SGF-2010, it still has plenty of room for improvements such as incorporating more disclosures on Sharí ${ }^{`}$ ah non-compliant events, providing more information on zakat and charity collection and distribution and including more disclosure on Sharī'ah functions.

At the time this research was conducted, SGPD-2019 had not been released. However, the framework was later reviewed, and the analysis revealed that more focus is given to the integration of Shar'̄'ah governance activities in business and risk strategies and more reference and authority are given to the BOD as compared to SGF2010. Interestingly a separate section is provided in SGF-2017 and SGPD-2019 on transparency and disclosure which was not included in SGF-2010, requiring more elaboration on processes for forming an opinion in the SC. A clear definition of Sharīah non-compliance risk is also provided in this guideline. A more elaborate outline of SC members, chairman and secretariat is also presented. However, the requirement for two-thirds votes when making decisions is relaxed to "simple majority". There is a new requirement for at least one member of the SC to have Islamic banking and finance background. Finally, the recently released SGPD-2019 has relaxed the requirement for having a minimum of five $\mathrm{SC}$ members for Islamic windows or a foreign branch in Malaysia to a minimum of three SC members. In addition, a new rule is introduced where the services of SC for a particular IFI should not be more than nine years.

This research can be extended in various ways. Future studies can replicate the present research to other IFIs, more specifically in the takaful (Islamic insurance) industry. They could investigate improvements in Sharī ah governance practices that evolved through the issuance of guidelines and regulations and look into the relationship between Shari ${ }^{-} a h$ governance and performance in the takâful industry. Another significant extension of the current research could be done by developing a Sharīah governance index for its core components to more systematically quantify Sharī'ah governance practices. This could provide a platform for further quantitative analysis of the relationship between Sharīah governance and different aspects of performance. Future research could also look into the impact of Sharī'ah functions such as Sharī'ah review, audit, risk and research on Sharī'ah governance practices and bank performance, given the importance of these functions highlighted by the results in this research. 


\section{References}

Abdul Rahman, A., Abu Bakar, B. and Syafie, A.W. (2005), "Syariah governance of Islamic banks: perceptions of responsibility and independence of Syariah advisors", in Hassan, V., Shanmugam, B. and Perumal, V. (Eds), Corporate Governance: An Islamic Paradigm, University Putra Malaysia, Serdang.

Bhatti, M. and Bhatti, I. (2009), "Development in legal issues of corporate governance in Islamic finance", Journal of Economic and Administrative Sciences, Vol. 25 No. 1, pp. 67-91.

BNM (2019), "Shariah governance", available at: www.bnm.gov.my/index.php?ch=57\&pg=144\&ac= $836 \& b b=$ file (accessed 3 March 2020).

Casper, M. (2012), "Sharia boards and Sharia compliance in the context of European corporate governance", Working paper, Center for Religion and Modernity, University of Münster, Münster.

Chapra, M.U. (2016), The Future of Economics: An Islamic Perspective, Kube Publishing, Markfield, Vol. 21.

Farook, S.Z. and Farooq, M.O. (2011), "Shari'ah governance for Islamic finance: challenges and pragmatic solutions", Working paper, Bahrain Institute of Banking and Finance.

Fatihah, A.R. (2015), "Shari'ah governance disclosure by Islamic banks in Malaysia”, $\mathrm{PhD}$ Thesis, Universiti Utara Malaysia.

Febianto, I. (2011), "Shari'ah compliant model of business entities", World Journal of Social Science, Vol. 1 No. 4, pp. 130-149.

Field, A. (2009), Discovering Statistics Using SPSS, Sage Publications, New York, NY, NJ.

Ginena, K. and Hamid, A. (2015), Foundations of Shari' ah Governance of Islamic Banks, John Wiley and Sons, Chichester, West Sussex.

Hamza, H. (2013), "Sharia governance in Islamic banks: effectiveness and supervision model", International Journal of Islamic and Middle Eastern Finance and Management, Vol. 6 No. 3, pp. 226-237.

Hasan, Z. (2012), Shari' ah Governance in Islamic Banks, Edinburgh University Press, Edinburgh.

Kamaruddin, M.I.H., Hanefah, M., Shafii, Z., Salleh, S. and Zakaria, N. (2020), "Comparative analysis on Shariah governance in Malaysia: SGF 2010", Journal of Public Administration and Governance, Vol. 10 No. 1, pp. 110-131.

Laldin, M.A. and Furqani, H. (2018), "Islamic Financial Services Act (IFSA) 2013 and the Sharīahcompliance requirement of the Islamic finance industry in Malaysia", ISRA International Journal of Islamic Finance, Vol. 10 No. 1, pp. 94-101.

Muhammad, S.F. and Sulong, Z. (2019), "Corporate and Shariah governance mechanisms and earnings quality in Islamic banks: a review and evaluation of patterns", in Sidek, N., Said, R. and Hasan, W. (Eds), Islamic Development Management, Springer, Singapore.

Omar, N.B. (2013), "Shariah governance framework: a mitigating mechanism against money laundering and terrorism financing in Islamic financial institutions", Paper presented at the Islamic Accounting and Financial Criminology Conference (IAFCC 2013), 23 March, Shah Alam, Selangor.

Rahaman, F.B.A. (2015), "Sharī'ah governance disclosure by Islamic banks in Malaysia”, PhD Thesis, School of Business, Universiti Utara Malaysia.

Ramli, N.M., Majid, A.S.A., Muhamed, N.A. and Yaakub, N.A. (2014), "Shari'ah governance disclosure index and institutional ownership of Islamic financial institutions in Malaysia", Proceedings of 5 th Asia-Pacific Business Research Conference, 17-18 February, 2014, Hotel Istana, Kuala Lumpur.

Shafii, Z., Abidin, A.Z., Salleh, S., Jusoff, K. and Kasim, N. (2013), "Post implementation of Sharīah governance framework: the impact of Shari' ah audit function towards the role of Shari'ah committee", Middle East Journal of Scientific Research, Vol. 13, pp. 7-11.

Zikmund, W.G. (2003), Business Research Methods, South-Western Cengage Learning, Mason, OH. 
BNM (2010), Shariah Governance Framework for Islamic Financial Institutions, Bank Negara Malaysia, Kuala Lumpur.

BNM (2017), "Shariah governance - exposure draft", available at: www.bnm.gov.my/index.php?ch= en_announcement\&pg=en_announcement\&ac=587 (accessed 22 September 2018).

\section{About the authors}

Babak Naysary, PhD, is currently an Assistant Professor at the Faculty of Business, INTI International University. His areas of expertise are accounting and finance.

Marhanum Che Mohd Salleh, $\mathrm{PhD}$, is an Associate Professor in the Department of Finance at the International Islamic University Malaysia. Her areas of expertise include Islamic finance, takäful, Islamic marketing and Sharī'ah. Marhanum Che Mohd Salleh is the corresponding author and can be contacted at:marhanum@iium.edu.my

Nurdianawati Irwani Abdullah, $\mathrm{PhD}$, is an Associate Professor in the Department of Finance at the International Islamic University Malaysia. Her areas of expertise include Islamic law, Islamic finance and takâful.

For instructions on how to order reprints of this article, please visit our website: www.emeraldgrouppublishing.com/licensing/reprints.htm Or contact us for further details: permissions@emeraldinsight.com 